\title{
The Sanskrit Inscription of Śankara and Its Interpretation in the National History of Indonesia
}

\author{
Arlo Griffiths \\ École française d' Extrême-Orient, Paris, France; \\ UMR 5189, Histoire et Sources des Mondes Antiques, Lyon, France \\ arlo.griffiths@efeo.net
}

\begin{abstract}
It is a well-known fact that Sanskrit had a relatively shorter and less prolific lifespan in the epigraphy of Indonesia, particularly in the Javanese epigraphic record, than in that of other Southeast Asian regions. All the more precious, therefore, are the rare opportunities to add a Sanskrit inscription to the historical record of Java and learn more of how the Sanskrit language was deployed on the island to represent events recorded for posterity. In this article, I offer my edition and interpretation of the inscription referred to in Indonesian publications as Prasasti Sankhara (sic, with $k h$ ), that is, the Inscription of Śankara; debunk the entirely unfounded interpretation which it has received in successive reprints and editions of the greatly influential Sejarah nasional Indonesia (National history of Indonesia); and show the real historical interest of this inscription.
\end{abstract}

\section{Keywords}

Sanskrit - inscription - Śaivism - Buddhism - temple/candi - Śailendra - Mataram Java

\section{Introduction}

J.G. de Casparis, who died in 2002, was the last great specialist of Indonesian epigraphy who was competent in Sanskrit, but he stopped publishing inscriptions early on in his career. If I am not mistaken, not a single previously unpublished Sanskrit inscription from Java has been published by a trained Sanskrit 
scholar in nearly 70 years, since an article by De Casparis dating to $1961 .^{1}$ The work of this scholar has been greatly influential. This is true especially for two large volumes, dating respectively to $195^{\circ}$ and 1956, which contain editions and translations of numerous inscriptions in Old Malay, Old Javanese, and Sanskrit, along with elaborate discussions of the historical problems on which the epigraphical documents in question throw light. De Casparis followed in the footsteps of several earlier scholars by focusing his attention on the dynastic history of Central Java in the second half of the first millennium: the questions of the geographic origin of the Śailendra dynasty; of royal patronage of Hinduism versus Buddhism; and of the possible role of foreign, that is, non-Javanese, political power in these matters. In order to weave a consistent historical narrative, he often resorted to rather extreme speculations to tie rare facts together, and has been justly criticized for this by his French contemporary, Louis-Charles Damais, who devoted to De Casparis's books a book-length review of 225 pages in $B E F E O$ volume 54 (1968), published two years after his death. In the apologetic opening footnote of this review (p. 295, n. 1), we read:2

Actually, I believe that there is already an excess of theories that have been put forward particularly regarding the ancient history of Java, and I wanted above all to warn against the acceptance of solutions that may be seductive but that seem to me insufficiently supported by the documents, or even plain conjecture. I would prefer, in other words, to return to the scrupulous study of original documents while avoiding as much as possible to confuse more or less hypothetical deductions - which one is of course entitled to make, on the condition that it happens with measurewith facts that are proven beyond doubt or are sufficiently corroborated.

The same questions and speculative reconstructions have not ceased to occupy historians of ancient Indonesia of the generation after De Casparis, and we will see that the interpretation of the inscription of Śankara has suffered from a biased, nationalistic framework of interpretation and from a deficient competence in Sanskrit on the part of the responsible historian-epigraphist.

Both De Casparis and Damais were acknowledged as teachers by the late Boechari (d. 1991), who in turn taught the current generation of senior epigraphists in Indonesia, and has during his career prepared numerous 'provi-

1 I am excluding here my own work, for instance my publication on the Balekambang inscription in this journal (Griffiths 2012).

2 For the convenience of an international readership, I have translated all quotations from languages other than English into that language. 
sional transcriptions' of newly discovered inscriptions, most of which were never formally published during his lifetime but have been collected and published in the volume Melacak sejarah kuno Indonesia lewat prasasti / Tracing ancient Indonesian history through inscriptions (2012). One of the inscriptions that were included there is the inscription of Śankara. ${ }^{3}$

Boechari, definitely a very serious and admirable scholar, despite the weighty criticism that I will bring forward in this article, was responsible for many of the epigraphic contributions to volume II, entitled Zaman kuno, of the Sejarah nasional Indonesia ( $S N I$ ), the National history of Indonesia, a major collective publication which was launched in the 1970s and of which new editions and reprints have appeared continuously since the first edition in 1975, most recently in an edisi pemutakhiran, or updated edition, that appeared in 2008 and has been reprinted several times since. ${ }^{4}$ Without quoting more than one verse-quarter of its original text, but referring to his own transcription, Boechari in $S N I$ vol. II uses data from the inscription to support far-reaching reconstructions of Indonesian dynastic and religious history, on the basis of the imagined conversion from Śaivism to Buddhism of its protagonist, named Śankara, who is presumed to have ruled as king in the eighth century CE. His dating of the inscription on palaeographic grounds, and his reading into it of the 'conversion' of a 'king', allow Boechari to tie together the patronage activities of monarchs whom he would otherwise have felt constrained to attribute to two different dynasties, one of which would ostensibly have to be 'foreign', according to a narrative that was dominant in Boechari's time and hasn't entirely lost its appeal to some scholars even today. ${ }^{5}$

To set the stage, I need to quote what are presumably Boechari's own words at length, while highlighting some elements that demand special attention: ${ }^{6}$

3 Because it was never published during his lifetime, the inscription is missing in the overview, by now rather outdated, of Sanskrit inscriptions from Indonesia and Malaysia that was offered by De Casparis 1991.

4 On Indonesian national and nationalist historiography, see Reid 1979. I cite $S N I$ vol. II from the 4th edition (Bambang Sumadio 1990) and the updated edition (Bambang Sumadio and Endang Sri Hardiati 2008).

5 By way of example, let me cite Van Naerssen 1947, Bosch 1952, and Jordaan and Colless 2009. For further references, see the section 'A critical review of the single-dynasty and two-dynasty theories' in Long 2014 (pp. 79-84). Mark Long, an amateur scholar whose work is laudable but also shows many weaknesses, ignores the short paper on the same topic included as Chapter 11, 'Satu atau dua dinasti di kerajaan Matarām Kuno', in Boechari 2012. Boechari's thinking was strongly influenced by the reaction published by Poerbatjaraka (for instance, in his 1958 article) to the aforementioned articles by Van Naerssen, Bosch, and others.

6 I am translating from $S N I$ vol. II (1990), pp. 91-3, including notes 20 and 21. I do so with 
From the inscription of Sojomerto it is clear that Dapunta Selendra was a follower of Śaivism. When and for what reason the kings of the Śailendra dynasty began to follow Buddhism may perhaps be known from an inscription owned by Adam Malik, which we will provisionally refer to by the name Inscription of Sankara. This inscription is in Sanskrit, but regrettably only its final part has been found. It seems that the inscription was engraved on two stones, but the first stone which contained the beginning of the text is not available. We therefore do not know when the inscription was issued - if it contained any date at all. In view of the unevenness of the back of the inscription, and the presence of parts that stick out, it seems that this inscription used to be placed in some building.

The remaining part contains the information that at a certain time the father of King Śankara fell ill, and for eight days he suffered badly because of a burning fever. Finally, he died without his priest teacher being able to cure him. For this reason, King Śankara then felt afraid of his teacher, whom he considered wrong, and he consequently abandoned his devotion to Śankara (the god Śiva). The concluding part of the inscription indeed suggests that King Śankara later became a follower of Buddhism, for it is stated among other things that he gave a favour to the bhikṣusañgha.

[...] Actually this interpretation is still rather doubtful. The matter rests on the interpretation of the sentence that runs so yan tyaktānyabhaktir jagadaśivaharāc chañkarāc chankkarākhyah, above all the ablative case jagadaśivaharāc chainkarāc. Can this sentence be translated by 'him, who is called Śankkara, who abandoned his devotion to others, (among others) from Śiva, who removes the world's disorder'? Indeed this sounds quite odd, but keeping in mind that the final portion of the inscription suggests that the King Śankara became a follower of Buddhism by making a donation to the bhikșusangha, it is very possible that this oddness results from the limited comprehension of the writer of the inscription, who very probably was a native scholar, with regard to Sanskrit grammar. [...] What also attracts attention is the information that King Śankkara refers to his teacher as 'a bad teacher' (anrtaguru).

silent adjustment of the punctuation and spelling of some words, including the fact that Boechari consistently writes Śangkhara instead of Śangkara (my Śankara), and the insertion of a few quotation marks. The corresponding pages of the (only very superficially modified) edisi pemutakhiran (2008) are $117-8$. 
If this interpretation is correct then we find here an epigraphical source that offers information about the conversion of religion from Śaivism to Buddhism, and the king who converted was King Śankara, whose name has not hitherto been found in the sources known to us.

This inscription being incomplete, the year to which it dates is unknown. However, from a palaeographic perspective it may be estimated that it dates from the middle of the eighth century CE. It thus very probably constitutes epigraphical evidence for the theory of Poerbatjaraka based on information in the Carita Parahyanan. In other words, it is very likely Poerbatjaraka who was right with regard to the pedigree of the Śailendra dynasty, namely that they were native Indonesians, and that there was only one dynasty, the Śailendra dynasty, whose members initially followed Śaivism, but from the government of Rakai Panankaran onwards became followers of Mahāyāna Buddhism, later to convert again to Śaivism after the government of Rakai Pikatan.

We need to mention here the idea that the complete title of Rakai Panankkaran was very probably Rakai Panan̉karan Dyah Śankara Śrī Sañgrāmadhanañjaya. ${ }^{7}$

Summarizing the historically important points, Boechari believed that Śankara was a 'native Indonesian'; that he was a king of the Śailendra dynasty, none other than the Rakai Panankaran famous from the inscriptions of Kalasan ( 778 $\mathrm{CE})$, Mantyasih I (907 CE), and Wanua Tengah III (908 CE); $;$ that he was the son of King Sañjaya; that he was initially a devotee of Siva who later converted to Buddhism; and that he did not write the inscription himself but that whoever did had only a mediocre command of Sanskrit. Against the background of these ideas, let us turn now to the inscription itself.

Provenance, Preservation History, and Physical Aspects of the Stone

The original provenance of the inscribed stone is unknown. Boechari first refers to the inscription as a recent discovery in two closely related papers published in $1975,{ }^{9}$ and mentions as 'very likely' one collector's report that it would have

\footnotetext{
$7 \quad$ This idea has been elaborated in a short paper by Bambang Budi Utomo (1989).

8 See Wisseman Christie 2001 and Sundberg 2009.

$9 \quad$ Boechari 1975a (= 2012:265-266) and Boechari 1975b $\left(=2012: 253^{-254}\right)$.
} 


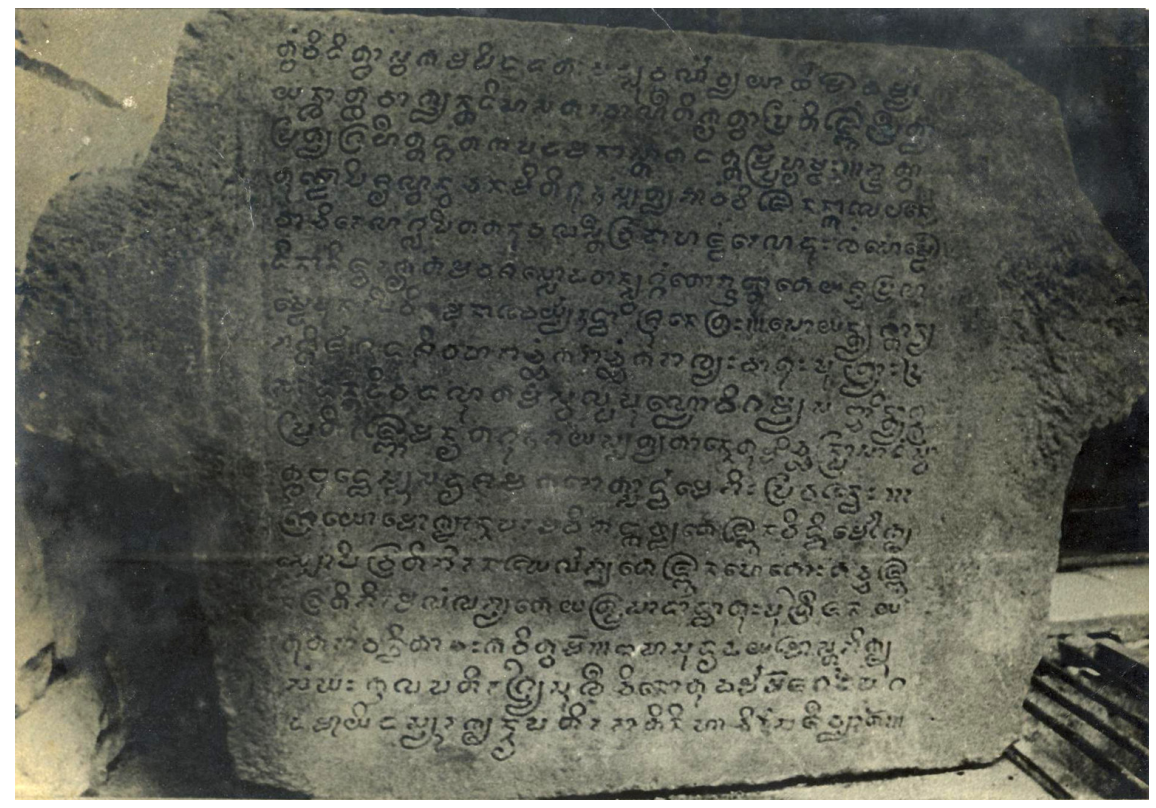

FIGURE 1 Black-and-white photo of the stone reproduced from SNI vol. II (1990), p. 99

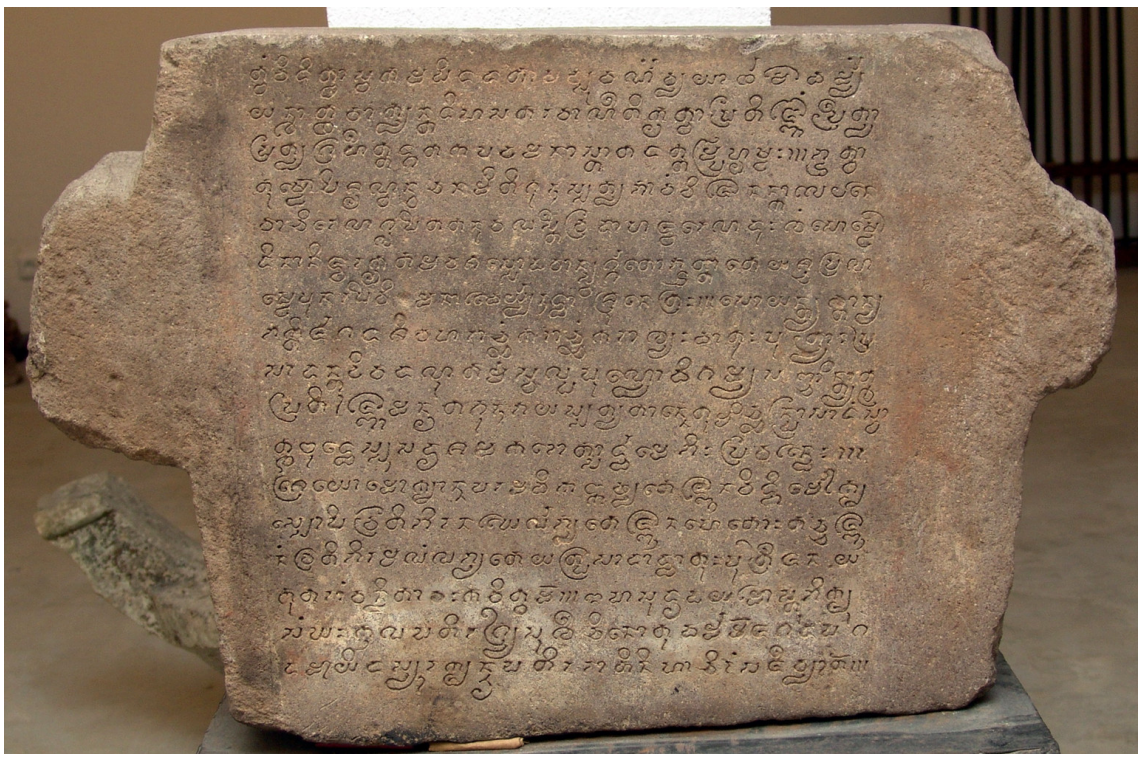

FIGURE 2 Colour photo of the stone (2019) 


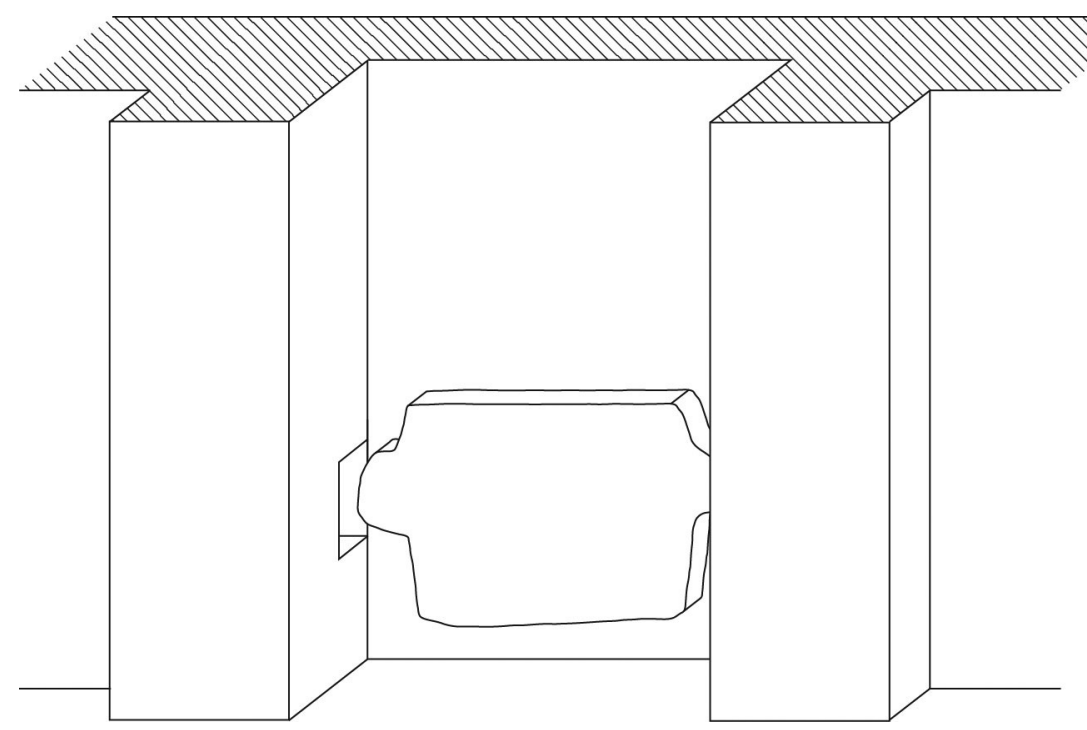

FIGURE 3 Schematic reconstruction by Véronique Degroot of the inscription's placement.

Not to scale

been unearthed in Central Java near Sragen, to the east of Solo. ${ }^{10}$ I do not know why Boechari considered this specific provenance to be so plausible, but at least it seems safe to assume that the provenance lay somewhere in Central Java.

After its discovery, the stone was acquired by Adam Malik, an important political figure under the Sukarno and Soeharto presidencies. After his death in 1984, his widow, Nelly Malik, took the initiative of founding a museum, but around the year 2000, the heirs were no longer able to keep this private museum going and several pieces were sold off so that the collection disintegrated.11

$10 \quad$ My translation of $S N I$ II (1990), p. 90 (= 2008:116), n. 16: 'According to information from Mr. Adam Malik, the seller of the inscription said that the stone originated in West Java. But there is information from a collector in Sala who told Boechari that the stone originates from near Sragen, to the eastern side of Sala, and that at the site in question remains of brick constructions are still found. That collector is still keeping a head of a Buddha statue of beautiful manufacture, made of terracotta. Keeping in mind the tendency of dealers in archaeological artefacts never to mention the provenance of the pieces they sell, and keeping in mind the contents of the inscriptions, it is very likely that it is the information from the collector in Sala which is correct.'

11 I rely here on information from an item published on 6 September 2008 on the online news portal liputan6.com (see 'Museum Adam Malik tinggal kenangan', https://www 
By the time I started studying the inscription, in 2009, nobody in Jakarta was able to tell me where the stone was kept. In that phase of my research, I had to rely on a black-and-white photograph published in $S N I$ II (1990, Fig. 1). The exact whereabouts of the inscribed stone in question are still unknown to me, but I do know that the stone resurfaced in 2019 in a private collection in Indonesia. The new owner had the kindness to send archaeologist Véronique Degroot a recent photo that I include here as Fig. 2. Based on this photo, and on the observations of Véronique Degroot, I can affirm that the preparation of this stone and the engraving of the text reveal a workmanship unrivalled in Indonesian epigraphy.

Although, as stated by Boechari, this single stone does not preserve the whole of the original inscription, the surface of the one stone that we do have has been exquisitely polished and stunningly well preserved, even to the point that there are traces of possibly original red paint on and around the inscribed surface. The stone is not large, measuring perhaps c. $50 \times 70 \mathrm{~cm}$. I agree with Boechari's suggestion that it was meant to be placed in a recess of the wall, such as a niche or a space between two pilasters (Fig. 3). The upper face of the stone is quite smooth. It is possible that it had been smoothed for the joint with the upper stone to be seamless. This upper stone, bearing the first part of the inscription, would have been attached to the wall with horizontal tenons as well.

\section{Edition and Translation of the Text}

My edition has been established on the basis of the aforementioned photographs. In footnotes, I report variant readings found in Boechari's edition (B) that I have myself prepared for publication since his death (Boechari 2012:4735) on the basis of two frequently varying typescripts (Figs. 4 and 5). In my edition, I hyphenate the Sanskrit text and insert apostrophes (') to mark elision of vowel $a$ - due to sandhi, although no avagraha sign is actually written in any instance. For these and other aspects of the transliteration system (notably the

.liputan6.com/news/read/164858/museum-adam-malik-tinggal-kenangan, accessed 7-122020); an item that was published on detikNews.com on 26 November 2008 but is no longer available now (defunct URL: https://news.detik.com/berita/d-1043374/museum -adam-malik-nasibmu-kini); and a blogpost by Djulianto Susantio ('Museum Adam Malik tak tersisa', https://hurahura.wordpress.com/2013/o1/o8/museum-adam-malik-tak -tersisa/, accessed 7-12-2020). 


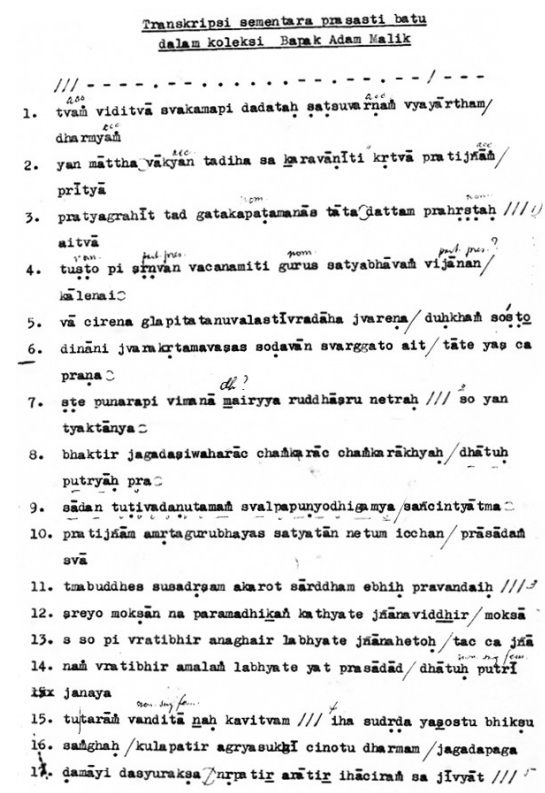

\section{FIGURE 4}

Undated typescript by Boechari: Transkripsi sementara prasasti batu dalam koleksi Bapak Adam Malik

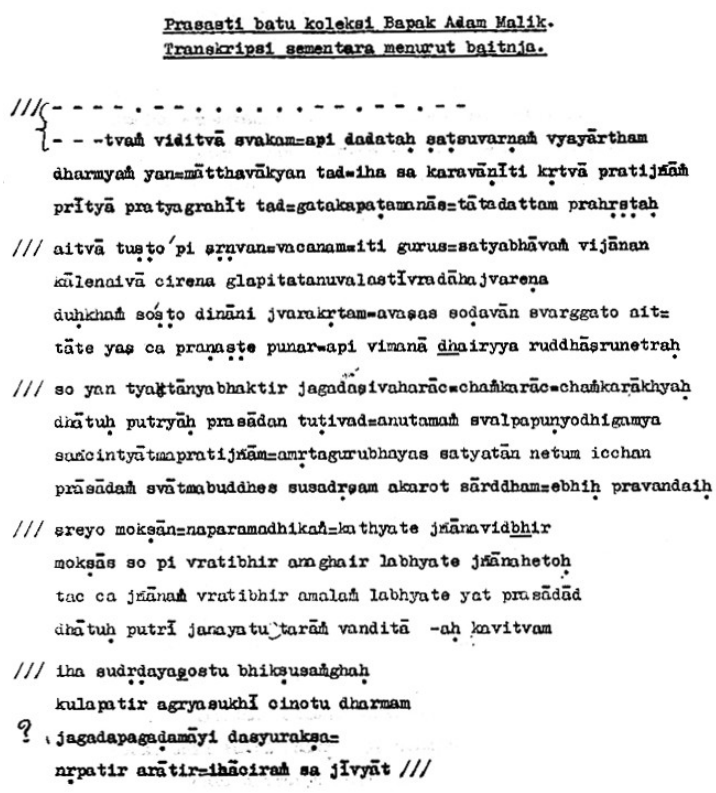

Prasagt1 batu kolekg1 Bapak Adam Malik. Irangiorips1 sementara menurut baitnia.

\section{FIGURE 5}

Undated typescript by Boechari: Prasasti batu koleksi Bapak Adam Malik: Transkripsi sementara menurut baitnja. The spelling -nja suggests it is datable to the early 1970s at the latest

use of capital letters for akșara vowels), which I apply also to Boechari's readings in my footnotes, see Balogh and Griffiths (2020). My translation is on many points different from that of Boechari, but I will discuss only the historically important differences in the next section.

'Having made the promise, "I here (sa) shall in this place (iha) do that, what virtuous words ( $v \bar{a} k y a)$ you speak (āttha) to me, ... having understood (viditvā) the ... -hood (-tvam) of one who himself gives six suvarnas for the purpose of expenditures (vyayärtham)", with pleasure he, being delighted and with a mind free of deception, accepted that which had been given by [his] father.' 
bhūtvā (4) tușțo 'pi śṛnvan vacanam iti gurus satya-bhāvami vijānan kālenai(5)vācireṇa glapita-tanu-valas tīvra-dāha-jvareṇa duḥkham̉ so 'ṣtau (6) dināni jvara-kṛtam avaśas sọ̣avān svar-ggato 'bhūt

tāte yaś ca praṇa(7)ștẹe punar api vimanā dhairyya-ruddhāśrunetrah $\left.||\right|^{12}$

'And (api) shortly thereafter the father (guru), who had become satisfied by hearing those words, who recognized the fidelity [underlying them], [but] whose bodily strength was exhausted due to a fever that burned sharply, after bearing fever-induced pain in powerless condition for eight days, reached heaven. And when his father had deceased, he once again became dejected, [although] thanks to his self-control (dhairya) the tears in his eyes were kept under control.'

\section{Metre: Sragdharā}

so 'yan tya(k)tānya(8)-bhaktir jagad-aśiva-harāc chamkarāc chamkarākhyah

dhātuḥ putryāḥ pra(9)sādan tuṭivad aṇutamam sv-alpa-puṇyo 'dhigamya

sañcintyātma(10)-pratijñām an-rota-guru-bhayas satyatān netum icchan prāsādam svā(11)tma-buddhes su-sadrośam akarot sārddham ebhị̣ pravandhaih ||${ }^{13}$

'He (that is, the present poet) here who was called Śankara, who had no other devotion than that to Śankara, the destroyer of what is inauspicious in [this] world, [and] who, being of very limited merit, obtained [only] the minutest atom — no more than a grain of cardamom—of grace from Dhātr's Daughter

12 a. bhūtvā: Aitva $\bar{B}$ - for other instances of this shape of $b h \bar{u}$, which Boechari didn't recognize here and in c, see the Canggal inscription (lines 3, 8, and 16) and especially the Kanjuruhan inscription (line 6). • c. ștau: șțo B • soḍavān: norm. soḍavān. •'bhüt: Ait B - vimanāa: an irregularity in the stone has forced the engraver to leave a space between $v i$ and ma. $\bullet$ dhairyyaruddhāśrunetrah: a descender from line 6 has forced the engraver to leave a space between $d d h \bar{a}$ and śru.

13 c. sañcintyātma-pratijñäm: a descender from line 8 has forced the engraver to leave a space between $s a$ and $\tilde{n} c i$, and another one from line 9 has done so between $t i$ and $j \tilde{n} \bar{a}$. $\bullet \mathrm{d}$. pravandhaih: norm. prabandhaih. 
(that is, of Sarasvatī, the patron goddess of poetry), having carefully considered his own promise, greatly fearing untruthfulness and wishing to bring [his promise] to realization, made a temple ( $p r a \bar{s} \bar{a} d a$ ) that conformed precisely to his own intention, together with these compositions.'

\section{Metre: Mandākrānta}

(12) śreyo mokṣān na param adhikañ kathyate jñāna-vidbhir mokșa(13)s so 'pi vratibhir an-aghair labhyate jñāna-hetoh tac ca jñā(14)nam vratibhir a-malam labhyate yat-prasādād dhātuḥ putrī janaya(15)tu-tarām vanditā (n)aḥ kavitvam· \|\|$^{14}$

'There is no greater Felicity (śreyas) than Release, say those who have access to Gnosis, and that Release is obtained by sinless ascetics on the grounds of [their] Gnosis. May Dhātrós Daughter, who is praised by us, and by whose grace the ascetics obtain that immaculate Gnosis, greatly stimulate [our] poetry.'

\section{Metre: Puspitāgrāa}

Iha su-drọ̣a-yamo 'stu bhikșu(16)-samghah kula-patir agrya-sukhī cinotu dharmam. jagad apaga(17)da-māyi-dasyu rakșan nr-patir arāti-nihā ciram sa jīvyāt ||||$^{15}$

'Let the community of mendicants remain steadfast in observance here (in this world); let the kulapati accumulate dharma (or: construct a monument) [so that he may one day become] possessed of Supreme Happiness; protecting the earth [so that it may become] free of (apagata) deceitful brigands, may the king, destroyer of enemies (aräti-nihan), live long here (on earth)!

14 b. mokṣas: mokṣās B • c: (n)ah: - -aḥ B.

15 a. su-drda-yamo: sudrdaya (ś)o B-norm. sudrdha-; the adopted reading -yamo is required both by grammar and by the form of the second akșara, which does not permit being read as śo. • c. apagada-: apagada- B—corr. apagata-; a descender from line 8 has forced the engraver to leave a space between $p a$ and ga. • cd. rakșan nr-: rakṣa-nr- B • d. arāti-nihā ciraṁ: arātir ihāciraṁ $\mathrm{B}$. 
Regarding the structure of the text, it is clear that we have preserved only the final portion of an originally longer inscription. We can be certain that the stanza here numbered $v$ was indeed the inscription's final stanza, both because of its contents (a wish for long life that is reminiscent of the Hampran and Balekambang inscriptions) ${ }^{16}$ and because of its metrical form (the Puṣpitāgrā metre that is used is a typical metre for concluding stanzas in Sanskrit poetics). ${ }^{17}$ Any possible dating of the inscription would have been contained in its opening portion and is now lost to us. We are therefore dependent on palaeographic arguments to establish its date. I will return to this issue below.

The king mentioned in the final stanza remains unnamed in the available part of the inscription. I do not think the epithet aräti-nihan 'destroyer of enemies' needs to be connected with the complex of epithets that are similar in meaning but not in sound (sarvāri-mada-vimathana, vairi-vara-vira-mardana, vira-vairi-mathana) found in inscriptions explicitly related with the Śailendra dynasty (Bosch 1952:116) — arāti-nihan can easily be considered as a stereotypical royal epithet, although I cannot exclude that the similarity is more than coincidental.

Contrary to Boechari's assumptions, there is absolutely no evidence that the author of the text was any other than the protagonist Śankara, ${ }^{18}$ nor that

16 Hampran, pāda d: tasyaitad bhānu-nāmno bhuvi bhavatu yaśo-jīita (m c)aiva nityam 'may it and the life of the fame of this one called Bhānu be eternal here on earth!' (my edition and translation, slightly different from those of De Casparis 1950:9-11)—Balekambang, second hemistich: tasya $C i \smile-\smile n \bar{a} m n a h$ jivitam etac cira( $m$ bhava)tu 'May this life (on earth) be long for this one called ...!' (cf. Griffiths 2012:475).

17 See Hooykaas 1955:22-8 (par. 7), esp. the table on p. 27. I owe to Dominic Goodall the following references for cases where Puṣpitāgrā is used as the end of a canto (sarga) in classic works of Sanskrit poetry: Raghuvamía 5.76, 6.86, 9.76-77; Kumārasambhava 4.46, 6.94; Saundarananda 6.49. It is also noteworthy that among Sanskrit works transmitted in Indonesia, the last stanza of the Kamahāyānan Mantranaya is likewise in Puṣpitāgrā (Kats 1910:30).

18 In an initial stage of interpretation, Boechari seems to have considered that the protagonist's name was Dasyurakșa. See Boechari 1975a:58 (= 2012:265-6): 'Penemuan-penemuan prasasti baru dalam sepuluh tahun terakhir telah menampilkan beberapa nama baru yang sebelumnya tidak dikenal oleh para ahli sejarah, seperti [...] dan Dasyurakșa di dalam prasasti berbahasa Sanskerta dari daerah Surakarta.' However, the corresponding passage in the same author's almost identically named and simultaneously published English-language article already used Śankkara instead of Dasyurakșa (Boechari 1975b:19 [= 2012:253-4]): 'The past decade alone has yielded several inscriptions promulgated by hitherto unknown personalities, such as the [...] recently discovered Sanskrit inscription probably dating from the eighth century, which mentions the name of Śankara who, after the death of his father, changed his religion from Śaivism to Buddhism.' 
this protagonist was the king, let alone that Śankara was part of the complete title of King Panankkaran..$^{19}$ Our Śankara can possibly be identified with one of the private persons called Śankara figuring in Damais's onomastic repertory (1970:542):

- Kayumwungan (746 Śaka), from the place called Trihaji

- Tunahan (794 Śaka), from the region called Mamali

- Mulak I (8oo Śaka), from Mulak

- Poh (827 Śaka), one from the village Kilipan and another from the village Sampū

Alas, our text contains no date, toponym, or other information that would allow us to confirm any particular identification, but only the first would be compatible with the date bracket that I will propose for the inscription below. At least it can be observed that none of these Śankaras was king, and that the name Śankara-spelt Śankkhara in some of these inscriptions but not in ours-was quite common on Java in the ninth century CE.

I also disagree with Boechari's arguments that are based on the assumption that the author of the text had only limited competence in Sanskrit. My impression is that the author of the text, who identifies himself as Śankara in stanza III, was quite an accomplished Sanskrit poet. Only one real error is found in the text: the misspelling of voiced $d a$ for unvoiced $t a$ in $p \bar{a} d a \mathrm{c}$ of stanza $\mathrm{v}$, which may have been induced by the pattern jagadapagada-. The spelling of $d$ for $d h$ (lines 6 and 15) reflects a regional spelling standard and cannot be deemed a mistake.

In stanza I, the phrase dadatah șat-suvarnam vyayārtham. contains what may be the earliest attestations in Javanese epigraphy of the terms suvarna and the term vyaya to denote, respectively, a particular weight in gold and expenditures related to pious foundations. Although either one of these terms by itself

19 I have nowhere seen this made explicit, but I assume that Boechari felt that the idea 'that the complete title of Rakai Panankkaran was very probably Rakai Panankkaran Dyah Śañkara Śrī Sangrāmadhanañjaya' was supported by the possibility of explaining the Old Javanese word panañkaran as derived with $\mathrm{paN}$-..-an circumfix from a base śankara. Personally, I find it much more likely that the underlying base is the word recorded with spelling sankkr in Zoetmulder 1982, as spellings with $a$ and $a$ were in almost free variation in early specimens of Old Javanese. A line in the kakavin Bhomāntaka (38.19d) shows the close association of the idea of a 'limit' with the power of a king: anhin sira tiki makadandaniti sira sankor amuput i jagat 'only he administers the law; he is the outermost limit of the world' (the translation 'But only he who has chastisement as his policy is the spoke that reaches to the outer limits of the world' proposed by Teeuw and Robson 2005:263 seems less satisfactory). The same association transpires from a phrase in the unpublished Pūrvädhigama (cited by Zoetmulder 1982 under the entry rājanīti): vruha ri sərikarnin śäsananira '(the king) should know the limits of his commands'. 
is a perfectly normal Sanskrit word, their co-occurrence reveals that the particularly Javanese mix of Sanskrit metrological and administrative terminology was already in place by the time of the inscription's composition. The oldest dated co-occurrence that I am aware of is found in the ninth-century Old Javanese inscription Kwak I (801 Śaka), lines 1v13-15, where the term ryaya figures in the Javanized spelling byaya and suvarna in the common abbreviation $s u:^{20}$

Ekapiṇ̣a byāyanim manìma mas su kā 1 su 11 mas. mā 4 mas. ku 3

'Total of the expenses for demarcating the freehold: 1 kāṭi and 11 suvarna in gold, 4 māṣa and 3 kupañ in gold'

In stanza II, I find the sequence śrṇvan vacanam iti somewhat peculiar, but I have assumed that it can perhaps stand as equivalent to śrnvvan etad vacanam 'hearing those words'. Not to speak of Boechari's obviously impossible interpretation of the sequence tyaktānyabhaktir jagadaśivaharāc chamkarāc in stanza III, which he himself admitted to be odd and whose oddness he explained away by accusing the poet of incompetence, the late scholar was clearly not aware of the possibility of interpreting an-rta-guru-bhayas in this stanza quite differently, namely by taking guru not as 'teacher' but in its literal sense of 'heavy', and joining it with bhayas rather than with an-rta. It is this solution that yields my translation 'greatly fearing untruthfulness', which makes much better sense in the context.

In stanza IV, I am unable to detect specifically Śaiva or specifically Buddhist tenets. The emphasis on the salvific power of Gnosis is common to both religions. The main problem of interpretation, however, and one that is related to this question about stanza IV, lies in stanza v. What is clear, is that there is no question of a donation to the bhikssusangha, let alone of any conversion to Buddhism. The problem, as I see it, is whether any connection with Buddhism may be assumed at all.

With the words dharma and bhikșusangha, we would at first sight seem to be placed squarely in a Buddhist context. But this interpretation, which would have as corollary that a Śaiva poet Śańkara composed a final stanza in support of Buddhist institutions, is not necessarily correct. The use of the word bhikșu, to begin with, is not the monopoly of the Buddhists. It generally denotes a beg-

$20 \quad$ See Wicks 1986 and Wisseman Christie 2004 on the Javanese metrological system and on the various measures of weight in gold used in these examples, notably on the suvarna. 
gar in some of the most fundamentally 'Hindu' texts in Sanskrit. ${ }^{21}$ It is also used in manuals (paddhati) for sectarian Śaiva practice to refer to initiates belonging to a set-up under an ācārya, but in one context only, namely when they speak about going out to beg for food (bhikșā). The author Somaśambhu, for instance, details various possible arrangements for food in a Śaiva monastic context, and the topic is complicated. But it is clear that begging is highly rated, since it seems that the Śaiva initiate raises up the level of everyone's Dharma by receiving alms (dharmonninișayā bhikșām bhikṣur abhyādadīta tām). ${ }^{22}$ The word possibly gained a more general usage in Śaiva circles in Indonesia, where it occurs in a few texts in the Old Javanese language, some of them specifically Saiva. ${ }^{23}$ It is noteworthy, in this connection, that one of the most common and

21 By way of example, I may cite Mānavadharmaśāstra 3.94 krtvaitad bali-karmaivamatithim pūrvam āśayet | bhikṣām ca bhikșave dadyād vidhivad brahma-cāriṇe 'After completing in this manner the Bali offering, he should feed a guest before anyone else and give almsfood to a mendicant student of the Veda according to rule'; 3.243 brähmanam bhikṣukam vāpibhojanārtham upasthitam | brāhmaṇair abhy-anujñātah śaktitah pratipūjayet 'Should a Brahmin or a mendicant come there for food, he should honor him according to his ability with the permission of those Brahmins'; 6.51 na tāpasair brāhmanair vā vayobhir api $\bar{a} \bar{a}$ śvabhih |ākìrnam bhikṣukair vānyair agāram upasam̃vajet 'He should never visit a house crowded with ascetics, Brahmins, birds, dogs, or other beggars'; 8.36o bhikșukā bandinaś caiva dīkṣitāḥ kāravas tathā | sambhāṣanam saha strïbhị̣ kuryur a-prativāritāḥ 'Mendicants, bards, men consecrated for sacrifice, and artisans may converse with women, unless they have been explicitly banned'; 11.02 navaitān snātakān vidyād brāhmaṇān dharma-bhikṣukān | niḥ-svebhyo deyam etebhyo dānam vidyā-viśeșatah 'these nine should be known as "bath-graduates", Brahmins who are beggars pursuant to the Law. Gifts must be given to these destitutes in proportion to their eminence in vedic learning.' The edition and translation cited are those of Olivelle (2005). See also the synonyms listed in Amarakośa 2.6.897-9o1: bhikṣuḥ parivrāț karmandīpārāśary api maskarī| tapasvītāpasaḥ pārikānikși vācamyamo munị̣| tapaḥ-kleśa-saho dānto varnino brahma-cārinah | rșayaḥ satya-vacasaḥ snātakas tv āpluto vratī $\mid$ ye nir-jitendriya-grāmā yatino yatayaś ca te.

22 Somaśambhupaddhati volume 1, section 9. See Brunner 1963:312-3, stanza 26. I owe this reference and the observations on the larger context to Dominic Goodall. On the usage of bhikṣu in Śaiva Sanskrit texts, see also Acri 2008:199-200, especially notes 31 and 37.

23 Vratiśāsana (ed. Sharada Rani 1962), Sanskrit stanza 27: yathā bhāskara-candrayor ahonaktam samam dyutih | tadvad gamanam bhikșoś ca hrdayam na vivarjitam, with Old Javanese paraphrase ... eva man்kana tāmbəkanta viku | hayva anaku pañavruh | mvan sarvaguna $\mid$ hayva kalipyan denin trimala | sattva rajah tamah || mañkana lin bhațāra śankara | kayatnakna tmon || nihan vara-varah bhațāra śambhu keñatakna. See also Vrhaspatitattva (ed. Sudarshana Devi 1957), paraphrase of stanza 25: pravrajyā naranin viku anāśaka | bhikṣu naranin dīkșita. The Amaramālā part of the Candrakiraṇa lists as synonyms: ... munīśvara, yogī, dharmajña, viku, rși, bhikșu, bhujañga, kalyānaadharma, budha, yati, mahāmuni, yatīndra, bhikșuka, tāpasa ṅaran saì paṇdita ika (ed. Lokesh Chandra 1997:198-9). 
earliest attested Javanese terms to designate a (Śaiva) mendicant is viku, which is generally believed to be a loanword based on a Middle Indo-Aryan form of bhikșu. ${ }^{24}$

Our devout Śaiva poet was therefore quite possibly aware of the Śaiva meaning of the term. He may have been playing consciously on its Buddhist associations by placing it in the direct vicinity of the words dharma and a verb-form cinotu that is derived from the same root as caitya, and moreover inserting it in a compound with sangha, but the latter word too is not the exclusive property of Buddhist Sanskrit, nor is the word dharma or the root $c i$. However, it is also possible that, despite Śankkara's personal devotion to Śiva, this final stanza is to be read at a more general level of public affairs, and that the community of Buddhist monks is actually intended, or perhaps that all mendicants are intended without regard for their religious affiliation. This would then help to explain the use of the term agrya-sukhi which, as far as I am aware, has no Śaiva but does potentially have a Buddhist connotation. ${ }^{25}$

The word kulapati, on the other hand, is certainly not a Buddhist term but is found in explicit association with 'Hindu' (Vaiṣnava and Śaiva) temples and monastic institutions elsewhere. See, for instance, the inscription of Mundeśvarī Hill in Bihar, India, re-edited and discussed by Neuss (2003), or the following inscription from a Vaișnava context in Nepal, dating to the 66os CE, where we read: ${ }^{26}$

kaś cit prasāda-śāsana-pațțako 'bhūt sa ca pūrva-rāja-vibhramato nașțo 'dhunāsmābhiś cirantana-vyavasthānupālana-jātādaraiḥ sa eva prasādaś cira-sthitaye śilā-paț̣akābhilekhyena prasādī-kṛto 'tra ca maryādā kulapatinā deyā kārtika-śuklaikādasyām mārga-samiskārārthan tạ̣ḍ̄la-mānikā 4

24 See item 5 in Hoogervorst 2017.

25 Cf. the prayer sarve sattvāḥ sarve prānạḥ sarve bhütāśca kevalāḥ| sarve vaḥ sukhinaḥ santu sarve santu nirāmayāh |, discussed by De Casparis (1956:338) on the basis of a Javanese attestation.

26 Regmi 1983, Vol. 1, no. 122, lines 7-11. I am grateful to Diwakar Acharya for helping me with the translation and informing me about the date of this inscription. In an email of 11 May 2020, he informs me: 'This inscription is now situated near a Śaiva temple but internal evidence tells that it concerns management and use of the property donated to the temple of Lokapālasvāmin, obviously a Vaiṣnava deity. For, it mentions that Kārtika śukla dvādaśī (the next day after Viṣnu rises from his sleep; the day of pārāyaṇa of the vaiṣnava cāturmāsya) is the day of installation of the deity and all other festivals mentioned are on ekādaśī or dvādaśí; it also mentions varāhayātrā.' 
'There was a charter of a (royal) grant (prasāda) but that got lost due to the negligence (vibhrama) of the previous kings, and now by us, being attentive to maintenance and protection of ancient arrangements, that very grant has been gracefully bestowed through an inscription on a slab of stone for the sake of its long endurance. And in this connection, there is the rule: on the eleventh (tithi) of the waxing (fortnight) of Kārtika, 4 mānikās of rice should be given for the sake of repair of the (processional) path by the person in charge of the temple (kulapati).'

For a Śaiva context, I may refer to the Cambodian inscription K. 180 (dated 869 Śaka / 948 CE), stanza XXIV (ed. Cœdès 1913:20):

sveșām māheśvarānām yaḥ kulānām patir āśrame māheśvarāśramābhikhye rājñām kulapatir mmatạ̣

'The one who was the chief of his own groups in the cloister of the Māheśvaras (that is, Śaivas) called Māheśvarāśrama was considered the abbot (kulapati) of the kings.'

The term kulapati is not found, as far as I am aware, in other Sanskrit sources from Indonesia, but it has been borrowed into Old Javanese. There do not seem to be any occurrences in Old Javanese literary works - and in epigraphic contexts too, from Java and Bali, the term is not very common-but there is a noticeable spike in inscriptions of tenth-century East Java. The meaning is not evident from the contexts that I have seen, but the following three passages from the lists of witnesses in two unpublished inscriptions issued by King Sindok suggest that the word had the same range of meanings as illustrated by the Sanskrit inscriptions cited above: ${ }^{27}$

- Paradah I (856 Śaka) Iveșnava kulapati si suvarnnna punta kabayan si baluk

'For the Vaiṣnavas, the kulapati [called] si Suvarṇa and the punta kabayan [called] si Baluk'

- Muncang (866 Śaka)

kulapati I sam hyam śāla I himad dạ̇ hyam marama vinaih pasakpasak mas mā 1 ku 2 vdihan yu 1

27 I quote from typed transliterations found among the unpublished papers of J.G. de Casparis kept at Leiden University Library. 
'The kulapati of the sacred hall at Himad [called] dan hyan Marama was given as gifts 1 māṣa and 2 kupan of gold and one set of cloth' kulapati Im kabikuAn i muñcam si rekal bapani sandhi, I lumbam-lumbam vinkas dapu dadak, gardama, kulapati Im kabikuAn i lumbamlumbaì kālị si humur bapani sakut, si pāda bapani baśrī

'The kulapati of the monastery at Muñcan [called] si Rekal, father of Sandhi; at Lumban-Lumban, the vinkas [called] Ḍapu Dadak [and] Gardama; the two kulapatis of the monastery at Lumban-Lumban [called] si Humur, father of Sakur, [and] si Pāda, father of Baśrì'

In no Old Javanese context that I have seen is kulapati used in connection with a recognizably Buddhist institution.

Returning now to our inscription, it seems possible, perhaps even likely, that Śankkara, who refers to himself in the third person in stanza III, does so again in stanza $\mathrm{v}$ and that the kulapati is none other than himself. Whether or not this interpretation is correct, the above evidence has made clear that the kulapati intended in stanza v was probably an abbot of a Śaiva monastic institution or manager of a Śaiva temple.

\section{The Problem of Dating}

Let us now turn to the question of dating. Boechari dated the stone to around the same period as the Kanjuruhan inscription from near Malang in East Java, which dates to 682 Śaka or 76 o CE, but felt it might be a bit earlier. ${ }^{28}$ This means that the inscription would have to be placed somewhere close in time to the inscriptions of Canggal (653 Śaka, $73^{2} \mathrm{CE}$ ) and Balekambang, both of which use the stiff/squarish script style that is usually called 'late Pallava,',29 and the Hampran inscription ( 672 Śaka, 75 O CE), which, like Kanjuruhan, uses the more cursive script style usually called 'Kawi'. It is this last script style that we also see deployed in the present inscription, but with a workmanship, glyph-size, and elegance that far surpasses the Hampran (Fig. 6) and Kanjuruhan (Fig. 7) specimens - a difference that complicates palaeographic comparison.

28 Boechari 1975b:26-7, n. 9 (=2012:253-4, n. 9): 'Our supposition that it might originate from the eighth century A.D. is based on palaeographical considerations. The script shows close resemblance to that of the stone inscription of Kāñjuruhan dated 760 A.D., and actually seems even more archaic.'

29 I am now less confident about my proposal (Griffiths 2012:477) to date the Balekambang inscription to the second half of the seventh century. It is really impossible to be sure, so a broad date bracket $65^{\circ}-75^{\circ} \mathrm{CE}$ is perhaps advisable. 


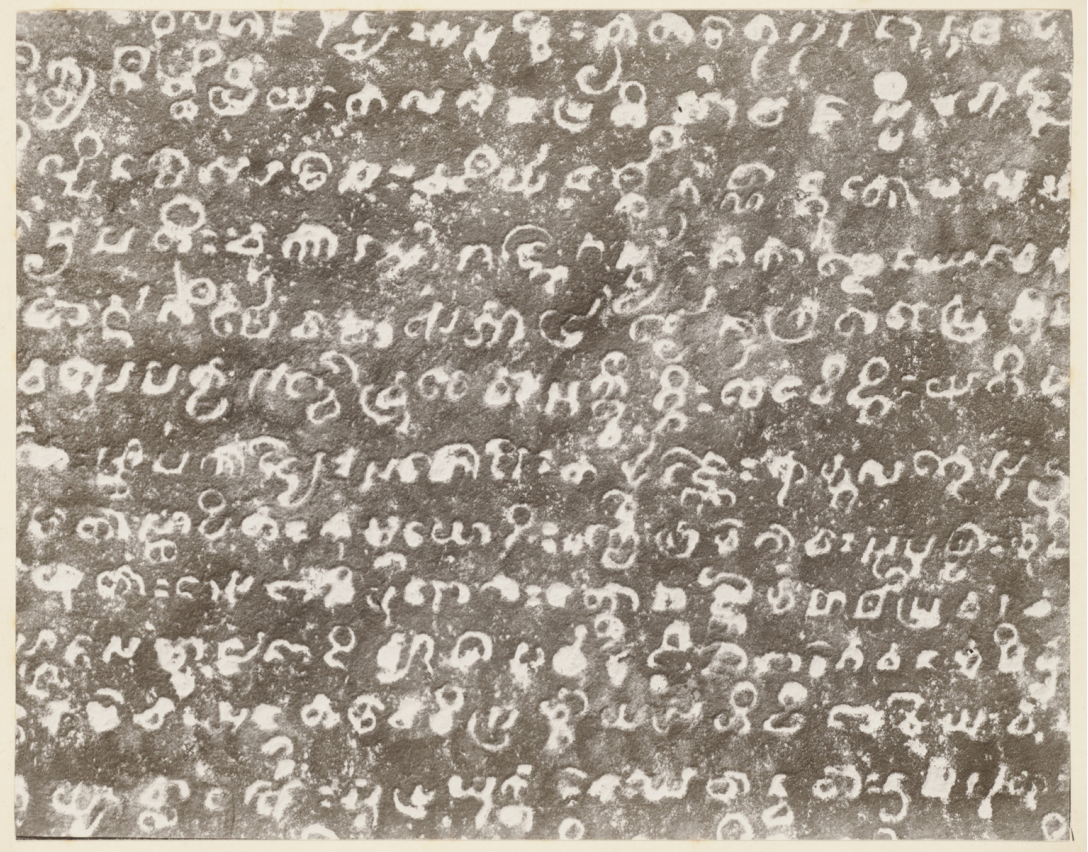

FIGURE 6 Photo OD 1504 showing a part of an estampage of the Kanjuruhan inscription

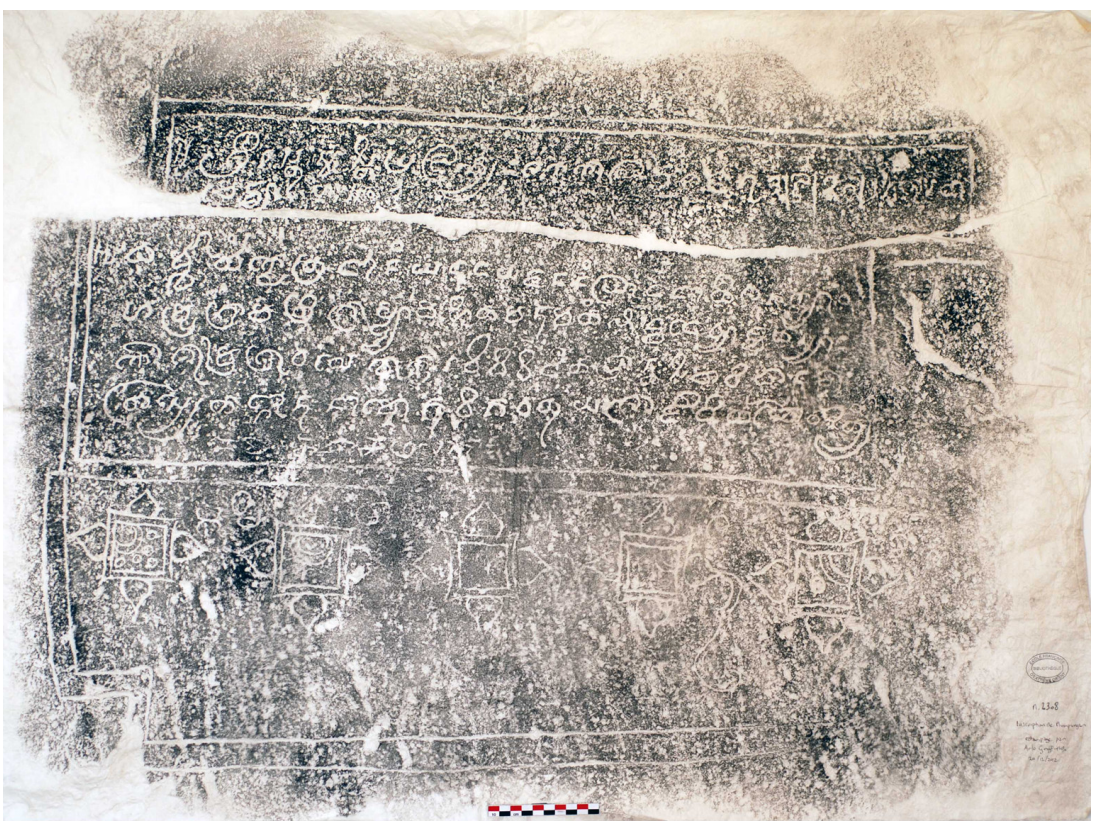

FIGURE 7 Estampage EFEO n. 2308 of the Hampran inscription 
It was no doubt Boechari who, in a parenthetic remark in SNI II (1990:124 [2008:156]), mentioned the similarity of shape of the virāma signs in the Kanjuruhan and Śankara inscriptions and assigned this shared feature to the middle of the eighth century. But in fact the inscription shows two different shapes: contrast its shape in vyayärtham in line 1 with that seen in kavitvam. in line 15, dharmam in line 16, and jiryāt. at the very end. And in his review of De Casparis's work, Damais (1968:504) had already pointed out that this pointer is not useful for narrowing down any specific dating between the middle of the eighth and the middle of the ninth century CE.

I do not believe that the problem can be solved exclusively on the basis of palaeographic arguments and would like to draw attention to the relevance of text-internal elements. The first is the very elusive possibility, mentioned above, that aräti-nihan in stanza $\mathrm{V}$ is to be connected with epithets of similar meaning in the Śailendra inscriptions which date to the last quarter of the eighth century CE. The second is the equally elusive possibility of identification of our protagonist Śankkara with one of the Śankkaras from the inscriptions, with better chronological and geographical grounding, listed above. Even the earliest of these (Kayumwungan, 746 Śaka / $824 \mathrm{CE}$ ) would situate us three quarters of a century later than Boechari's estimate. ${ }^{30}$ The third is the fact that we now have three Sanskrit inscriptions from Central Java-Hampran, Balekambang, and Śankara - which share the characteristic of expressing a wish for long life in their final stanzas. ${ }^{31}$ Of these three, only the Hampran inscription bears a date, which Damais (1970:43) thought to be equivalent to 75 O CE. Personally, I am inclined to attach chronological significance to this last element, and provisionally to retain Boechari's dating estimate, although it is impossible to exclude that a poet several decades or even a century later would have chosen to express the same theme, while the exceptionally monumental character of the script used for our inscription renders palaeographic comparison with any of the other early Kawi-script inscriptions from Java methodologically problematic, so that a later date cannot be excluded on palaeographic grounds either. Until new data become available that will make it possible to narrow it down, it is necessary to allow a wide date bracket, say $730-830 \mathrm{CE}$.

30 I do not have access to a usable reproduction of the Kayumwungan stele to compare its script with that of our inscription. From Sundberg's comparison (2008:116-9) of the script of the Kayumwungan stela with that of the short inscriptions on the reliefs of the hidden base of Borobudur, I gain the impression of a script style somewhat different from that which we are trying to date in the Śankara inscription. But a difference in style does not necessarily mean a difference of date. 
The interpretation of the inscription in Sejarah nasional Indonesia reveals a number of tendencies that reflect the comparatively unsophisticated level of historical analysis that was the norm in the 1970s and 1980s and that is, alas, still the norm today in studies of the early history of Indonesia. These are: (1) an unwillingness to admit that the pieces of the historical puzzle that have been passed down to the present are more likely to be disconnected from each other than to be able to be woven together into a coherent historical narrative; (2) a belief that all important inscriptions were issued by monarchs; and (3) the assumption that royal patronage of religious institutions was to the benefit of either Śaiva or Buddhist establishments and that simultaneous patronage of more than one religion was exceptional. ${ }^{32}$ His framework of historical analysis being determined by such misconceptions, and insufficiently controlled by his ability to understand what the Sanskrit text actually says, Boechari could present as 'epigraphical evidence' a series of ideas that constitute an almost complete misrepresentation of the data. The larger-scale narrative built up on such a basis, seen in the second paragraph of the following quotation (SNI II, 1984:109 [= 2008:138]), is therefore very misleading:

From the above analysis, we can imagine that the king of Matarām San Ratu Sañjaya had built back up the kingdom Ho-ling after King Sanna had fallen in battle due to a hostile attack, and the centre of his kingdom has been destroyed. In the year $717 \mathrm{CE}$, Sañjaya was inaugurated as king of Mədan, which was possibly situated at Poh Pitu. In the year $73^{2}$ CE he established a sanctuary for the worship of the linga on top of the Gunung Wukir, as a symbol of the fact that he had once again subjugated the minor kings around him, who had formerly acknowledged the suzerainty of King Sanna.

But at a certain moment he fell ill and died, in tremendous suffering during eight days, because he wanted to comply with what his teacher had said. His son, called Śañkara, or possibly in complete form Rakai Panaṅka-

32 With regard to point 1 , see the seminal article of Henige (1975) about a similar tendency in Indian historiography, aptly described as 'abhorrence of a vacuum'. With regard to point 2 , see the clear distinction made between royal donative inscriptions and private donations in Salomon 1998, par. 4.1.1-4.1.3. The misconception in point 3 has been effectively debunked in several recent publications: see Sanderson 2009:117-23 (the section entitled 'Joint patronage of Buddhism and Śaivism in the kingdoms of the Khmers, Chams, and Javanese'); Schmiedchen 2011; Pal 2014; and Sanderson 2015:198-207. 
ran Dyah Śaṅkara Śrī Śangrāmadhananjaya, because he was in fear of the teacher who was wrong, then abandoned Śaivism, becoming a follower of Mahāyāna Buddhism, and moved the centre of his kingdom eastwards, possibly around Sragen at the eastern side of Bengawan Solo, or to the area of Purwodadi/Grobogan.

My new reading, translation, and interpretation mean that the inscription loses any pertinence to dynastic history, or to the existence of Buddhist vestiges in the Sragen area. ${ }^{33}$ The protagonist of this inscription was called Śankara and not Śankhara, ${ }^{34}$ and his lifetime cannot confidently be assigned to the middle of the eighth century. This figure was not a king but a Śaiva poet with a very sound command of Sanskrit, who possibly served as abbot of a community of Śaiva mendicants (bhikșusañgha), or as temple manager-depending on what kulapati means. The inscription records how he fulfils a promise made to his father to carry out the pious foundation of a temple ( prāsāada), presumably to house a linga as representation of Śiva, a private foundation but one that appears to have been perceived as somehow supportive of royal power. It thus constitutes one of the very few non-royal Sanskrit inscriptions of Java. And it offers us a glimpse of the religious motivations and the financial aspects of such a foundation. Finally, we gain with this inscription a precious piece of evidence for a refined local practice of Sanskrit epigraphy that seems to be on par with the contemporary tradition in Cambodia. ${ }^{35}$

33 On these Buddhist vestiges, see Boechari 2012:200-1.

34 See the editorial note * drafted by me on p. 474 of Boechari 2012: 'Melihat bacaan di sini, dengan jagadaśivaharāc chaṃkarāc chaṃkarākhyaḥ sebagai hasil sandhi untuk jagadaśivaharāt śaṃkarāt śaṃkarākhyaḥ, agaklah mengherankan bahwa secara konsisten di seluruh kesempatan Boechari merujuk pada prasasti ini beliau salah menulis nama tokoh ini dengan ejaan Śankhara. Kesalahan tak sengaja ini kami perbaiki di segenap kasus di dalam buku ini.' See also my n. 6 above.

35 Pollock (2006:125-32) has given a useful comparative overview of the history of the use of the Sanskrit language in Cambodia and on Java. However, I believe he was quite mistaken about Cambodia and not entirely correct regarding Java in noting the following about the early Sanskrit inscriptions of these cultures (2006:130): 'As in the case of Khmer inscriptions, these Javanese texts are all royal records; inscriptional practice seems not to have extended outside the court—one significant difference from the Sanskrit cultural order in South Asia, where nonroyal records abound.' As other examples of non-royal (or at least not explicitly royal) Sanskrit inscriptions from early Java, I cite the Tuk Mas inscription, as well as the Hampran and Balekambang inscriptions that have already been mentioned above. For instances of non-royal Sanskrit inscriptions from Cambodia, I refer to Goodall 2015 and 2019. 


\section{Acknowledgements}

Begun early on during my posting at the EFEo Centre in Jakarta from 2009 to 2014, and initially presented at the World Sanskrit Conference held in Kyoto in September 2009, the research for this article then went dormant for ten years until there were two strong reasons for its resumption in 2019: the reemergence of the inscription and the launching of the project 'The Domestication of "Hindu" Asceticism and the Religious Making of South and Southeast Asia' (DHARMA), funded from 2019 to 2025 by the European Research Council (ERC) under the European Union's Horizon 2020 research and innovation programme (grant agreement no. 8o9994). On the project, see https://dharma .hypotheses.org. It is in the framework of this collective research endeavour that I have finally been able to bring this study to conclusion, and I thank my fellow project members Andrea Acri, Véronique Degroot, Dominic Goodall, and Annette Schmiedchen for their valuable suggestions on a draft of this article.

\section{References}

Acri, Andrea (2008). 'The Vaimala sect of the Pāśupatas: New data from Old Javanese sources', Tantric Studies 1:229-48.

Balogh, Dániel and Arlo Griffiths (2020). 'DHARMA transliteration guide'. https://hal .archives-ouvertes.fr/halshs-02272407.

Bambang Budi Utomo (1989). 'Rakai Paṇaṁkaran Dyāh Saṅkhara Śri Saṅgramadhananjaya', Amerta: Berkala Arkeologi 11:9-16.

Bambang Sumadio (ed.) (199o). Sejarahnasional Indonesia. 4th ed., 6th printing. Vol. II: Zaman kuno. Jakarta: Balai Pustaka.

Bambang Sumadio and Endang Sri Hardiati (eds) (2008). Sejarah nasional Indonesia. Edisi pemutakhiran. Vol. II: Zaman kuno. Jakarta: Balai Pustaka.

Boechari (1975a). 'Ken Angrok, anak Tunggul Ametung', Berita Antropologi 7-20:5669.

Boechari (1975b). 'Ken Aṅrok: Bastard son of Tungul Ametuṅ?', Majalah Ilmu-Ilmu Sastra Indonesia 6-1:15-33.

Boechari (2012). Melacak sejarah kuno Indonesia lewat prasasti / Tracing ancient Indonesian history through inscriptions. Jakarta: Kepustakaan Populer Gramedia (KPG); Departemen Arkeologi, Fakultas Ilmu Pengetahuan Budaya, Universitas Indonesia; École française d' Extrême-Orient.

Bosch, F.D.K. (1952). 'Çrîvijaya, de Çailendra- en de Sañjayavaṃça', Bijdragen tot de Taal-, Land- en Volkenkunde 108-2:113-23.

Brunner, Hélène (1963). Somaśambhupaddhati: Le rituel quotidien dans la tradition 
śivaïte de l'Inde du Sud selon Somaśambhu. Première partie. Pondichéry: Institut français d'indologie. [Publications de l' Institut français d' indologie 25.]

Casparis, Johannes Gijsbertus de (1950). Inscripties uit de Çailendra-tijd. Bandung: Nix \& Co. [Prasasti Indonesia 1.]

Casparis, Johannes Gijsbertus de (1956). Selected inscriptions from the 7 th to the gth century A.D. Bandung: Masa Baru. [Prasasti Indonesia 2.]

Casparis, Johannes Gijsbertus de (1961). 'New evidence on cultural relations between Java and Ceylon in ancient times', Artibus Asiae 24-3/4:241-8.

Casparis, Johannes Gijsbertus de (1991). 'The use of Sanskrit in inscriptions of Indonesia and Malaysia', in: Colette Caillat and Johannes Gijsbertus de Casparis (eds.), Middle Indo-Aryan and Jaina studies: Sanskrit outside India, pp. 29-41. Leiden: Brill. [Panels of the virth World Sanskrit Conference 6/7.]

Cœdès, George (1913). 'Etudes cambodgiennes', Bulletin de l'École française d'ExtrêmeOrient 13-1:1-36.

Damais, Louis-Charles (1968). 'Bibliographie indonésienne, XI: Les publications épigraphiques du service archéologique de l'Indonésie', Bulletin de l'École française d'Extrême-Orient 54:295-521.

Damais, Louis-Charles (1970). Répertoire onomastique de l'épigraphie javanaise (jusqu'àPu Siṇdok Śrī İśānawikrama Dharmmotungadewa):Étude d'épigraphie indonésienne. Paris: École française d'Extrême-Orient. [Publications de l'École française d'Extrême-Orient 66.]

Goodall, Dominic (2015). 'On K. 1049, a tenth-century cave-inscription from Battambang, and on the sectarian obedience of the Śaiva ascetics of non-royal caveinscriptions in Cambodia', Udaya: Journal of Khmer Studies 13:3-34.

Goodall, Dominic (2019). 'Nobles, bureaucrats or strongmen? On the "vassal kings" or "hereditary governors" of pre-Angkorian city-states: Two Sanskrit inscriptions of Vidyāviśeșa, seventh-century governor of Tamandarapura (K. 1235 and K. 6o4), and an inscription of Śivadatta (K. 1150), previously considered a son of İsānavarman I', Udaya:Journal of Khmer Studies 14:23-85.

Griffiths, Arlo (2012). 'The epigraphical collection of Museum Ranggawarsita in Semarang (Central Java, Indonesia)', Bijdragen tot de Taal-, Land- en Volkenkunde 1684:472-96.

Henige, David P. (1975). 'Some phantom dynasties of early and medieval India: Epigraphic evidence and the abhorrence of a vacuum', Bulletin of the School of Oriental and African Studies 38-3:525-49.

Hoogervorst, Tom (2017). 'The role of "Prakrit" in Maritime Southeast Asia through 101 etymologies', in: Andrea Acri, Roger Blench, and Alexandra Landmann (eds), Spirits and ships: Cultural transfers in early Monsoon Asia, pp. 375-440. Singapore: ISEAsYusof Ishak Institute.

Hooykaas, Christiaan (1955). The Old-Javanese Rāmāyaṇa kakawin: With special refer- 
ence to the problem of interpolation in kakawins. 's-Gravenhage: Nijhoff. [Verhandelingen van het Koninklijk Instituut voor Taal-, Land- en Volkenkunde 16.]

Jordaan, R.E. and B.E. Colless (2009). The mahärājas of the isles: The Śailendras and the problem of Śrivijaya. Leiden: Department of Languages and Cultures of Southeast Asia and Oceania, University of Leiden. [Semaian 25.]

Kats, J. (1910). Sang hyang Kamahâyânikan: Oud-Javaansche tekst met inleiding, vertaling en aanteekeningen. 's-Gravenhage: Nijhoff.

Lokesh Chandra (1997). 'Chanda-Karana: The art of writing poetry', in: Lokesh Chandra, Cultural horizons of India. Vol. 6: Studies in tantra and buddhism, artand archaeology, language and literature, pp. 140-85. New Delhi: International Academy of Indian Culture and Aditya Prakashan.

Long, Mark (2014). Voices from the mountain: The Śailendra inscriptions discovered in Central Java and the Malay Peninsula. New Delhi, Delhi: International Academy of Indian Culture and Aditya Prakashan. [Śata-Pițaka Series 648.]

Naerssen, Frits Herman van (1947). 'The Çailendra interregnum', in: India Antiqua: A volume of Oriental Studies presented by his friends and pupils to Jean Philippe Vogel, C.I.E. on the occasion of the fiftieth anniversary of his doctorate, pp. 249-53. Leiden: Brill.

Neuss, Jürgen (2003). 'The temple of Mundeśvarī: Reconsidering the evidence', Berliner Indologische Studien 15/16/17:531-85.

Olivelle, Patrick (2005). Manu's code of law: A critical edition and translation of the Mānava-Dharmásāstra. New York: Oxford University Press.

Pal, Sayantani (2014). 'Religious patronage in the land grant charters of early Bengal (fifth-thirteenth century)', Indian Historical Review 41-2:185-205.

Poerbatjaraka, R.M.Ng. (1958). 'Çrîvijaya, de Çailendra- en de Sanjayavamça', Bijdragen tot de Taal-, Land- en Volkenkunde 114-3:254-64.

Pollock, Sheldon I. (2006). The language of the gods in the world of men:Sanskrit, culture, and power in premodern India. Berkeley: University of California Press.

Regmi, Dilli Raman (1983). Inscriptions of ancient Nepal. 3 vols. New Delhi: Abhinav.

Reid, Anthony (1979). 'The nationalist quest for an Indonesian past', in: Anthony J.S. Reid and David G. Marr (eds), Perceptions of the past in Southeast Asia, pp. 281-98. Singapore: Heinemann Educational Books. [Asian Studies Association of Australia Southeast Asia Publications Series 4.]

Salomon, Richard (1998). Indian epigraphy: A guide to the study of inscriptions in Sanskrit, Prakrit, and the other Indo-Aryan languages. New York and Oxford: Oxford University Press.

Sanderson, Alexis (2009). 'The Śaiva Age: The rise and dominance of Śaivism during the early medieval period', in: Shingo Einoo (ed.), Genesis and development of tantrism, pp. 41-349. Tokyo: Institute of Oriental Culture, University of Tokyo. [Special Series 23.] 
Sanderson, Alexis (2015). 'Tolerance, exclusivity, inclusivity, and persecution in Indian religion during the early mediaeval period', in: John Makinson (ed.), Honoris causa: Essays in honour of Aveek Sarkar, pp. 155-224. London: Allen Lane.

Schmiedchen, Annette (2010). 'Religious patronage and political power: The ambivalent character of royal donations in Sanskrit epigraphy', Journal of Ancient Indian History 27:154-66.

Sharada Rani (1962). Wratiśāsana:A Sanskrittext on ascetic discipline with Kawi exegesis. New Delhi: International Academy of Indian Culture. [Śata-Pițaka Series (Dvīpāntara-pitaka) 20-5.]

Sudarshana Devi (1957). Wrhaspati-Tattwa: An Old Javanese Philosophical Text, Critically Edited and Annotated. Nagpur: International Academy of Indian culture. [ŚataPițaka Series (Dvīpāntara-Pițaka) 1.]

Sundberg, Jeffrey Roger (2008). 'Considerations on the dating of the Barabudur stūpa', Bijdragen tot de Taal-, Land- en Volkenkunde 162-1:95-132.

Sundberg, Jeffrey R. (2009). 'Appendix A-The state of Matarām: A review of recent efforts to clarify its history', in: Mark Long (ed.), Candi Mendut: Womb of the Tathāgata, pp. 329-62. New Delhi: Aditya Prakashan. [Śata-Pițaka Series 632.]

Teeuw, A. and S.O. Robson (2005). Bhomāntaka: The death of Bhoma. Leiden: KITLV Press. [Bibliotheca Indonesica 32.]

Wicks, Robert S. (1986). 'Monetary developments in Java between the ninth and sixteenth centuries: A numismatic perspective', Indonesia 42:43-77.

Wisseman Christie, Jan (2001). 'Revisiting early Mataram', in: M.J. Klokke and K.R. van Kooij (eds), Fruits of inspiration: Studies in honour of Prof.J.G. de Casparis, pp. 25-55. Groningen: Forsten.

Wisseman Christie, Jan (2004). 'Weight and values in the Javanese states of the ninth to thirteenth centuries A.D.', in: Pierre Le Roux, Bernard Sellato, and Jacques Ivanoff (eds), Poids et mesures en Asie du Sud-Est: Systèmes métrologiques et sociétés, 1: L'Asie du Sud-Est Austronésienne et ses marches, pp. 89-96. Paris: École française d'Extrême-Orient; Institut de Recherche sur le Sud-Est Asiatique. [Études Thématiques 13.]

Zoetmulder, P.J. (1982). Old Javanese-English dictionary. 2 vols. 's-Gravenhage: Nijhoff. 